\title{
PERFORMANCE OF CYCLE DIESEL ENGINE USING BIODIESEL OF OLIVE OIL (B100)
}

\author{
Desempenho de motor diesel quatro tempos alimentado com biodiesel de óleo de oliva (B100)
}

\author{
Carlos Eduardo Silva Volpato 1 , Alexon do Prado Conde ${ }^{2}$, Jackson Antonio Barbosa ${ }^{3}$, Nilson Salvador ${ }^{3}$
}

\begin{abstract}
Biodiesel is a renewable fuel derived from vegetable oils used in diesel engines, in any proportion with petroleum diesel, or pure. It is produced by chemical processes, usually by transesterification, in which the glycerin is removed. The objective of this study was to compare the performance of a four stroke, four cylinder diesel cycle engines using either olive (B100) biodiesel oil or diesel oil. The following parameters were analyzed: effective and reduced power, torque, specific and hourly fuel consumption, thermo-mechanical and volumetric efficiency. Analysis of variance was performed on a completely randomized design with treatments in factorial and the Tukey test applied at the level of 5\%. Five rotation speeds were researched in four replications $(650,570,490$, $410,320$ and $240 \mathrm{rpm})$. The engine fed with biodiesel presented more satisfactory results for torque, reduced power and specific and hourly consumptions than that fed with fossil diesel.
\end{abstract}

Index terms: Alternative fuel, energy efficiency, combustion engine.

\section{RESUMO}

Biodiesel é um combustível renovável derivado de óleos vegetais, usado em motores de ciclo diesel, em qualquer proporção com o diesel mineral, ou puro. É produzido por meio de processos químicos, normalmente por transesterificação, no qual é removida a glicerina. Este trabalho foi realizado com o objetivo de avaliar o desempenho de um motor de ciclo diesel quatro tempos e quatro cilindros, utilizando biodiesel de óleo de oliva (B100), em comparação ao óleo diesel. Foram analisados os parâmetros: potência efetiva e reduzida, torque, consumo específico e energético de combustível, eficiência termomecânica e volumétrica. Foi instalado um ensaio com delineamento inteiramente casualizado (DIC) em esquema fatorial, realizada análise de variância e aplicado teste de Tukey, a 5\%. Foram pesquisados cinco níveis de rotação em quatro repetições $(650,570,490,410,320$ e 240 rpm). O motor alimentado com biodiesel de oliva apresentou torque, potencia reduzida e consumos especifico e horário com resultados mais satisfatórios que o diesel fóssil.

Termos para indexação: Combustível alternativo, eficiência energética, motor de combustão.

(Received in february 14, 2012 and approved in may 30, 2012)

\section{INTRODUCTION}

Biodiesel is a renewable fuel derived from vegetable oils such as sunflower, castor oil plant (Ricinus communis), soybean, babassu palm (Attalea speciosa) and other oil seed plants, or from animal fats, used in diesel cycle engines, in any proportion with mineral diesel, or pure. It is produced by chemical processes, normally by transestherification, where the glycerin is removed. As alcohol used is to substitute gasoline in Otto cycle engines, biodiesel substitutes diesel oil in diesel cycle engines, with the advantage of not requiring mechanical adaptations. While the use of other clean fuels, such as natural gas or biogas and ethylic alcohol, requires adaptation, diesel combustion does not and it is a technical alternative that can serve all the existing vehicle fleet powered by diesel oil and also presents high energetic yield.
According to Law No. 9478/97, biofuel is the fuel derived from renewable biomass, for use in internal combustion engines or, depending on the regulation, for other types of energy generation that can partially or completely substitute fossil fuels.

Biodiesel production from crude vegetable oils has been the target of several studies in recent decades. In Brazil, the institution of the National Vegetable Oil Program Institution (OVEG, 1985) allowed tests to be carried out with vegetable oils of various chemical compositions and degrees of saturation. The main oils tested in this investigation were the derivatives of macaúba palm (Acrocomia aculeata), barbados nut (Jatropha curcas), indaiá palm (Attalea dubia), moriche palm (Mauritia flexuosa), pequi (Caryocar brasiliense), castor oil plant (Ricinus communis), soybean (Glycine max), babassu palm (Attalea speciosa), cotieira (Joannesia princeps Vell.), 1Universidade Federal de Lavras/UFLA - Departamento de Engenharia/DEG - Cx. P. 3037 - 37200-000 - Lavras - MG - Brasil - volpato@deg.ufla.br
${ }^{2}$ Companhia Energética de Minas Gerais/CEMIG - ACE Gerência de Planejamento e Expansão Sul - Varginha - MG - Brasil ${ }^{3}$ Universidade Federal de Lavras/UFLA - Departamento de Engenharia/DEG - Lavras - MG - Brasil 
tingüí (Magonia glabrata) and pupunha palm (Bactris gasipas).

According to Costa Neto (2000), the assessment of the carburant quality of vegetable oils requires the analytical determination especially of their calorific power, cetane index, distillation curve, viscosity and mist point Torres et al. (2006) tested a monocylinder stationary Agrale engine, model M-85 with $7.36 \mathrm{~kW}$ power and detected no significant differences regarding the use of diesel oil and biodiesel (B100) with very close results. The specific fuel consumption with $\mathrm{B} 100$ was approximately $20 \%$ greater than with diesel oil, the $\mathrm{CO}_{2}$ emissions were practically unaltered, but the $\mathrm{CO}$ emissions were much greater for the $4 \mathrm{~kW}$ power. The results showed the immediate possibility of substituting diesel oil with biodiesel as fuel in low power stationary engines.

Ferrari et al. (2007) use an electricity generator and soybean biodiesel obtained by oil transestherification with anhydrous ethanol in the presence of an $\mathrm{NaOH}$ Alkali catalyser, with $57 \%$ yield in the manufacture process. The portions of $5,10,20,40,60,80$ and $100 \%$ to commercial diesel oil were tested and the average consumption, in L. $h^{-1}$ in operation, in equipment kept under the same operating conditions. Decrease was observed in fuel consumption of $3.7 \%$ for $\mathrm{B} 5,5.9 \%$ for $\mathrm{B} 10,1.6 \%$ for $\mathrm{B} 20$ and there was a small increase in consumption in the other mixes.

Corrêa et al. (2008) evaluated the use of sunflower biodiesel blends (B5, B10, B20 and B100) and fossil diesel in a IC engine, direct injection. Was analyzed the performance of engine through power take-off (PTO) for each fuel. The lubricating oil was analyzed before and after period of 96 hours with B100. The results showed that the use of blends B5, B10, B20 and B100 decreased the power of PTO maximum 2,2\% and increased the fuel consumption maximum $7,3 \%$. The analyze of lubricating oil showed that the viscosity, water content and level of iron were the parameters more affected, although it had been acceptable.

Barbosa et al. (2008) evaluating the performance of an engine fueled with diesel oil and mineral mixtures with the proportion of biodiesel equivalent B2 (98\% mineral diesel and $2 \%$ biodiesel), B5 (95\% mineral diesel and 5\% biodiesel), B20 (80\% diesel mineral and 20\% biodiesel) and B100 (100\% biodiesel), concluded that the increased engine power respoectivamente the $\mathrm{B} 100$ to mineral diesel, however, in reverse order, the thermal efficiency of the diesel diminished mineral mixtures for growing biodiesel, and $4 \%$ lower for B100.

Volpato et al. (2009) tested the performance of a cycle diesel engine using biodiesel from soy oil (B100), as compared to fossil diesel. Where analyze the effective power and reduced power, rise, specific and energy consumption of fuel, efficiency term-mechanics and volumetric. The accomplished showed the viability of operation of a diesel engine with fuels substitute for soy oil (B100).

Nietiedt et al. (2011) evaluated the use of different blends of soybean methyl biodiesel (B10, B50 e B100) in comparison to the commercial diesel $\mathrm{B} 5$, with $5 \%$ of biodiesel added to the fossil diesel. The engine performance was analyzed trough the tractor power take off (PTO) for each fuel, The best performance occurred with the use of B5 and B10 fuel, without significant differences between these blends. The B100 fuel showed significant differences compared to the other fuels.

\section{MATERIAL AND METHODS}

The study was carried out in the Laboratory of Agricultural Machinery and Mechanization at the Department of Engineering at the Federal University of Lavras. An experiment was set up in a complete randomized design in a 2 x 6 factorial, with two types of fuel and six engine rotation speeds, with four replications.

The treatments used were commercial diesel oil and olive biodiesel (B100) at six engine rotation speeds: 650, $570,490,410,320$ and $240 \mathrm{rpm}$, that is, $100,88,75 \%, 63,49$ and $37 \%$ of the maximum rotation, respectively.

Analysis of variance (ANOVA) and the Turkey test at $5 \%$ were carried out using the Sisvar ${ }^{\circledR}$ computer program in the parameters of torque, effective power and hourly fuel consumption in function of the rotation at the tractor start up (TSU).

The diesel oil used in the experiments was obtained in the local automobile supply network. The biodiesel used was obtained from the Biodiesel Mill at Varginha with an ethylic base. The fuel specific mass and acidity index were determined in the Chemistry Laboratory at the Varginha Engineering Faculty in Varginha, MG. The higher calorific power was determined in the oil analysis laboratory at the Igarapé Thermal Electricity Plant, em Juatuba, MG, that is the property of Cemig. The dynamic and cinematic viscosity were obtained at the thermodynamic laboratory at the University of São Carlos - SP.

A new 275 Compact model Massey Ferguson tractor was used, with a four stroke, water cooled Perkins A4-4.1 model diesel oil cycle engine with an injection system with rotating pump, four cylinders in a line, total cylinder 4.100 $\mathrm{cm}^{3}$, with nominal power, according to the manufacturer, of $75 \mathrm{cv}(56 \mathrm{~kW})$, at $2.200 \mathrm{rpm}$.

The NBR ISO 1585 norm of the Brazilian Association of Technical Norms - ABNT (1996) was adopted to determine the torque values (N.m), RPM in TSU and power $(\mathrm{kW})$. These were obtained using an AW Dynamometer 
dynamometer model NEB 200 (Figure 1A). The respective values of torque, power and rotation were shown on a dashboard digital display, shown in figure 1B.
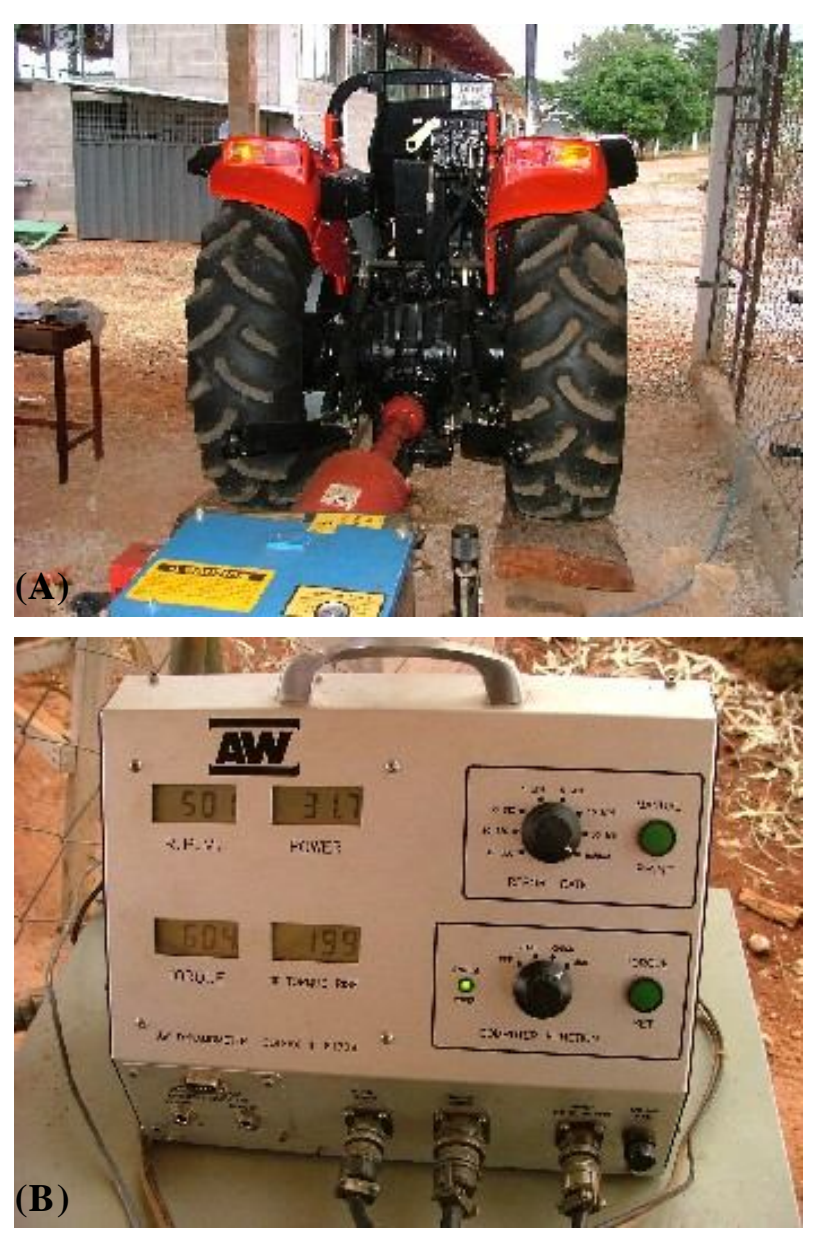

Figure 1 - Dynamometer attached to the tractor TSU (A) and digital display (B).

The hourly engine fuel consumption was determined by an Oval flow meter, model LSN41, together with its display, that was calibrated for reading in liters per

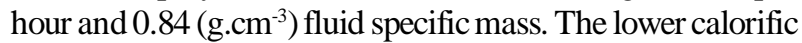

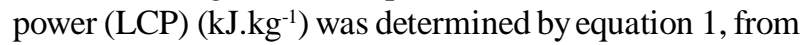

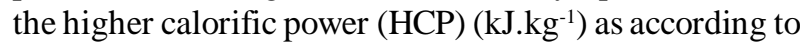
Moreira (2007).

$P C I=P C S-3052$

The effective power was shown directly on the display but it can be calculated as the torque $\mathrm{T}$ corresponding to the angular velocity by equation 2 (MIALHE, 1996).

$H_{e}=T \times N \times\left(\frac{2 \pi}{60 \times 1000}\right)$

where:

$\mathrm{H}=$ effective power $(\mathrm{kW})$;

$\mathrm{T}=$ torque (N.m);

$\mathrm{N}=$ angular speed $(\mathrm{rpm})$.

The reduced power obtained in the TSU was recalculated according to equation 3 (ABNT, 1995).

$\frac{H_{r}}{H_{e}}=\frac{P_{2}}{P_{1}}\left(\frac{T_{1}}{T_{2}}\right)^{0,5}$

where

$\mathrm{H}_{\mathrm{r}}=$ reduced power $(\mathrm{kW})$;

$\mathrm{H}_{\mathrm{e}}=$ effective power $(\mathrm{kW})$;

$\mathrm{P}_{1}=$ atmospheric pressure, at the time of the test $(\mathrm{mm} \mathrm{Hg})$;

$\mathrm{P}_{2}=$ standard atmospheric pressure $(760 \mathrm{~mm} \mathrm{Hg}) ;$

$\mathrm{T}_{1}=$ absolute temperature at the test $(\mathrm{K})$;

$\mathrm{T}_{2}=$ absolute standard temperature NBR ISO 1585/1996 (298 K).

The torque was measured by determining the intensity of a force that, acting on the extremity of an arm, tended to produce rotating movement. In the case of continuous rotating movement, the torque was measured by the dynamometer (MIALHE, 1996).

Equation 4 was applied to determine the specific consumption, according to Mialhe, 1996.

$C_{e}=\frac{C_{h}}{H_{e}}$

where:

$\mathrm{C}_{\mathrm{e}}=$ specific fuel consumption [g.(kW.h $)^{-1}$;

$\mathrm{C}_{\mathrm{h}}=$ hourly fuel consumption $\left(\mathrm{g} \cdot \mathrm{h}^{-1}\right)$;

$\mathrm{H}_{\mathrm{e}}=$ effective power $(\mathrm{kW})$.

\section{RESULTS AND DISCUSSION}

The curves for the two fuels presented the same performance as the torque curve declared in the NBR ISO 1585/1996. The Tukey test for torque for the fuels (Table 1) showed that the results of the average for olive diesel (B100) were different from diesel oil. 
Table 1 - Torque average for the fuels.

\begin{tabular}{cc}
\hline Treatments & Average (N.m) \\
\hline B100 oliva & $577.95 \mathrm{a}$ \\
Diesel oil & $645.20 \mathrm{~b}$ \\
\hline
\end{tabular}

Analysis of the torque effect in relation to the rotations (TSU) (Table 2) showed that the average values regarding the 240 and $570 \mathrm{rpm}$ rotations did not differ statistically at $5 \%$ probability, nor for the average values at 490, 410 and $320 \mathrm{rpm}$.

Table 2 - Torque average for the rotation speeds (TSU).

\begin{tabular}{cc}
\hline Treatments $(\mathrm{rpm})$ & Average $($ N.m) \\
\hline 240 & $559.25 \mathrm{a}$ \\
570 & $559.58 \mathrm{a}$ \\
490 & $626.58 \mathrm{~b}$ \\
320 & $626.92 \mathrm{~b}$ \\
410 & $648.42 \mathrm{~b}$ \\
\hline
\end{tabular}

The torque was measured using the polynomial expressions shown in figures 2 and 3 for the work rotation $540 \mathrm{rpm}$ (TSU) that is, $85 \%$ of the maximum. For diesel oil, the torque at $540 \mathrm{rpm}$ was $635.3 \mathrm{~N} . \mathrm{m}$ and 688.84 N.m for olive $\mathrm{B} 100$ that is, $8.43 \%$ greater.

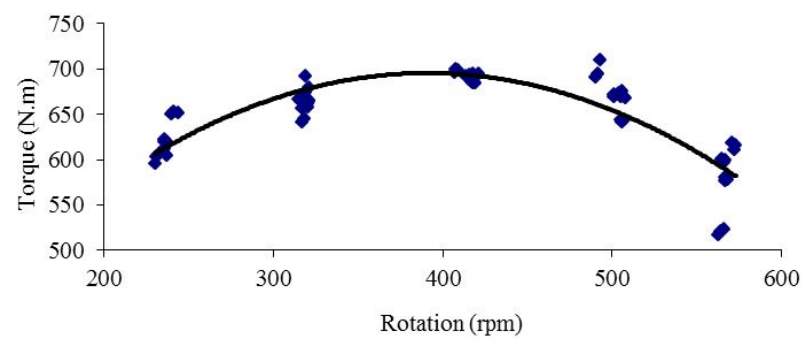

Figure 2 - Torque tendency curve for diesel oil.

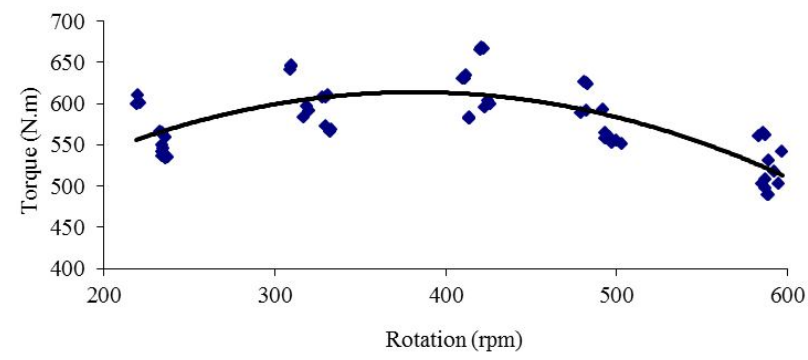

Figure 3 - Torque tendency curve for olive B100.
Table 3 shows the effective power average for the fuels tested. The results of the Tukey test at $5 \%$ probability showed that effective power for the fuels differed and the greatest value was attributed to diesel oil. It was further verified that the average power value for B100 was $12.7 \%$, less comparatively to diesel oil, showing that these fuels presented technically satisfactory results.

Table 3 - Effective power average for the fuels.

\begin{tabular}{cc}
\hline Treatments & Average $(\mathrm{kW})$ \\
\hline B100 oliva & $24.40 \mathrm{a}$ \\
Diesel oil & $27.50 \mathrm{~b}$ \\
\hline
\end{tabular}

When the effect of the effective power was analyzed in relation to the rotations (TSU), shown in table 4, it was observed that the average values for rotations from 490 and $570 \mathrm{rpm}$ did not differ statistically at $5 \%$ probability, unlike the other average values.

Table 4 - Effective power average in relation to the rotation speeds (TSU).

\begin{tabular}{cc}
\hline Treatments $(\mathrm{rpm})$ & Average $(\mathrm{kW})$ \\
\hline 240 & $14.83 \mathrm{a}$ \\
320 & $21.08 \mathrm{~b}$ \\
410 & $27.92 \mathrm{c}$ \\
490 & $32.42 \mathrm{~d}$ \\
570 & $33.67 \mathrm{~d}$ \\
\hline
\end{tabular}

Analysis of the results of the reduced power at the work rotation $(540 \mathrm{rpm})$ indicated that olive TSU presented the best result $(37.8 \mathrm{~kW})$. At the same rotation, $24.9 \mathrm{~kW}$ was obtained for diesel oil that represented a gain of $28.57 \%$ compared to diesel oil. Figures 4 and 5 show that the reduced power tendency curves performed similarly to those presented by Oveg (1985).

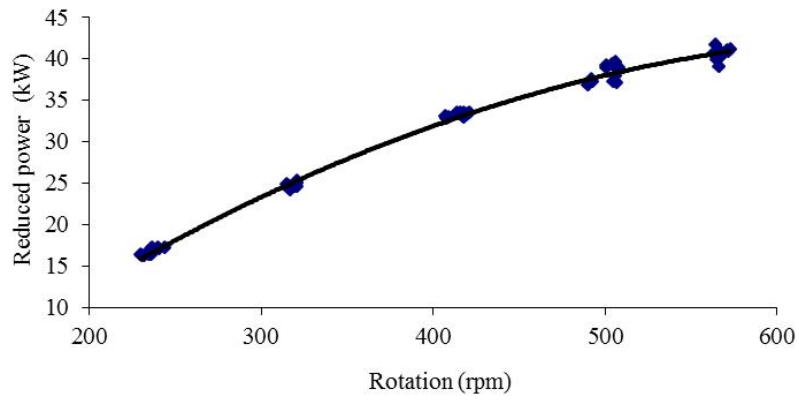

Figure 4 - Reduced power tendency curve for diesel oil.

Ciênc. agrotec., Lavras, v. 36, n. 3, p. 348-353, maio/jun., 2012 


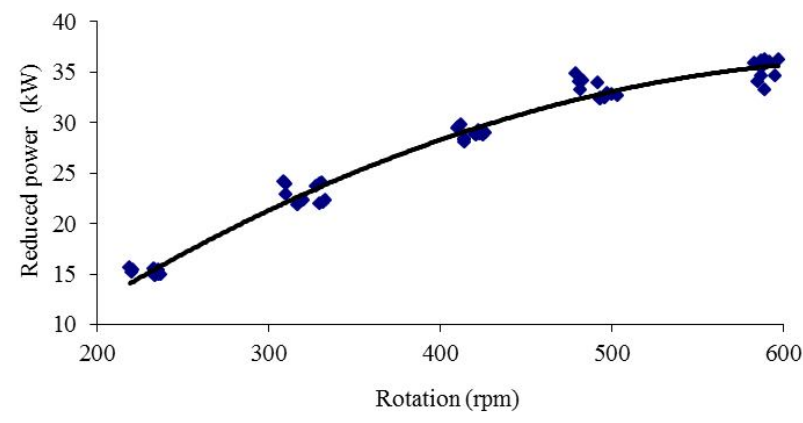

Figure 5-Reduced power tendency curve for olive B100.

Table 5 shows that the average hourly consumption values, for the fuels tested, differed by the Tukey test at $5 \%$ probability and the greater value was attributed to diesel oil. It was further verified that the average hourley consumption values of olive B100 were $30 \%$ less compared to diesel oil. It should be pointed out the tendency to low biodiesel consumption in engines with natural aspiration is due to the weakening of the mixture caused by it compared to diesel oil. However, it is a significant result in terms of specific consumption.

Table 5 - Hourly consumption average for the fuels.

\begin{tabular}{cc}
\hline Treatments & Average $\left({\left.\mathrm{L} . \mathrm{h}^{-1}\right)}^{-1}\right.$ \\
\hline B100 oliva & $6.60 \mathrm{a}$ \\
Diesel oil & $8.60 \mathrm{~b}$ \\
\hline
\end{tabular}

When the effect of hourly fuel consumption was analyzed in relation to the rotations (TSU), shown in table 6, the average values for the 490 and $570 \mathrm{rpm}$ rotations did not differ statistically at $5 \%$ probability, unlike the other average values.

Table 6 - Hourly consumption average in relation to the rotation speeds (TSU).

\begin{tabular}{cc}
\hline Treatments $(\mathrm{rpm})$ & Average $\left({\left.\mathrm{L} . \mathrm{h}^{-1}\right)}^{-1}\right.$ \\
\hline 240 & $5.75 \mathrm{a}$ \\
320 & $6.75 \mathrm{~b}$ \\
410 & $7.58 \mathrm{c}$ \\
490 & $8.58 \mathrm{~d}$ \\
570 & $8.92 \mathrm{~d}$ \\
\hline
\end{tabular}

Then the results for specific fuel consumption were analyzed regarding work rotation $(540 \mathrm{rpm})$, it was observed that diesel oil presented a higher average value of 258.84 g. $(\mathrm{kW} . \mathrm{h})^{-1}$. The olive B100 biodiesel presented the best result, 229.71 g.(kW.h) $)^{-1}$ or $12.68 \%$. Figures 6 and 7 show the tendency curves for the specific consumption of the fuel used.

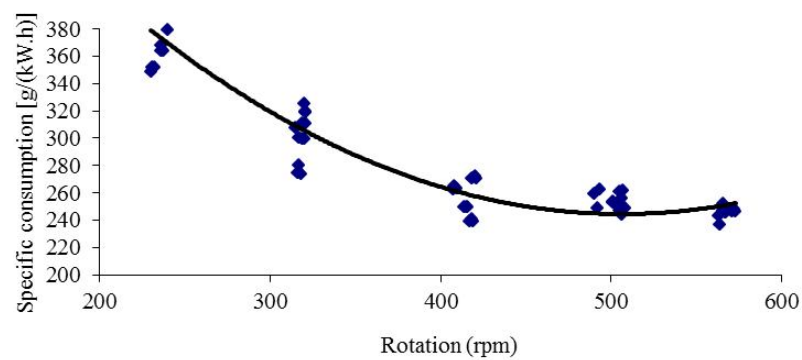

Figure 6-Specific consumption tendency curve for oil.

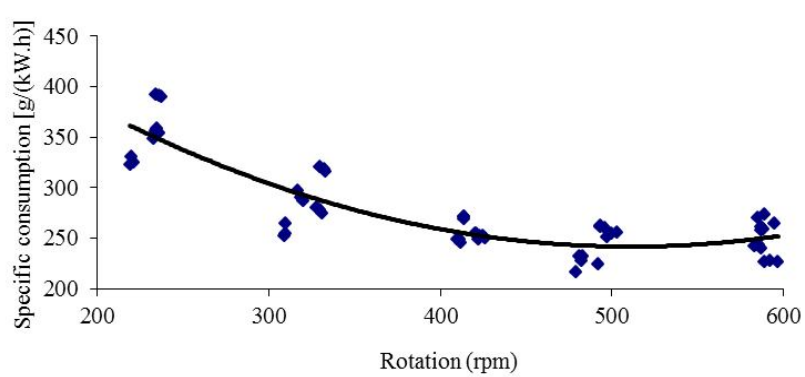

Figure 7 - Specific consumption tendency curve for olive B100.

\section{CONCLUSIONS}

The tests performed showed the feasibility of operating a diesel cycle engine with olive biofuel (B100).

There was gain in torque with the use of biodiesel, that was $8.43 \%$ greater than diesel oil at the work rotation.

Olive biodiesel obtained better reduced power results than fossil diesel oil, and $28.57 \%$ greater than diesel oil at the work rotation.

Olive biodiesel presented lower specific and energetic consumption compared to diesel oil that was 12.8 and $30 \%$, respectively, less at the work rotation.

\section{REFERENCES}

Associação Brasileira de Normas Técnicas - ABNT.

NBR ISO 1585. Veículos rodoviários: código de ensaio de motores: potência líquida efetiva. Rio de Janeiro, 1996. 
Associação Brasileira de Normas Técnicas - ABNT. NBR 13400. Determinação do desempenho na tomada de potencia: Método de ensaio. São Paulo, 1995.

BARBOSA, et al. Desempenho comparativo de um motor de ciclo diesel utilizando diesel e misturas de biodiesel. Ciência e Agrotecnologia, Lavras, v. 32, n.5, p. 1588-1593, set./out., 2008.

CORRÊA, I. M. Desempenho de motor diesel com misturas de biodiesel de óleo de girassol. Ciência e Agrotecnologia, Lavras, v.32, n.3, p.923-928, 2008.

COSTA NETO, P. R. et al. Produção de biocombustível alternativo ao óleo diesel através da transesterificação de óleo de soja usado em frituras. Química Nova, São Paulo, v. 23, p. 531-537, jul./ago. 2000.

FERRARI, R. A. et al. Produção e uso de biodiesel etílico na UEPG. Disponível em: <http://uepg.br/ propesp/publicatio/exa/2004_6/06.pdf>. Acesso em: 23 abr. 2007.
MIALHE, L. G. Máquinas agrícolas: ensaios \& certificação. Piracicaba: Editora FEALQ, 1996. 722 p.

MOREIRA, A. Combustíveis. São Carlos: USP-Escola de Engenharia de São Carlos, 2007. Apostila. Disponível em: <http://www.netef.eesc.sc.usp.br/moreira/ combustíveis.ppt $>$. Acesso em: 28 maio 2007.

NIETIEDT et al. Avaliação do desempenho de um motor de injeção direta sob diferentes misturas de biodiesel metílico de soja (Glycinemax). EngenhariaAgrícola. v.31, p.916-922,2011.

OVEG I. Óleos vegetais: experiência de uso automotivo. Brasília, DF: Ministério da Indústria e do Comércio, Secretaria de Tecnologia Industrial, 1985. 344 p.

TORRES, E. A. et al. Ensaio de motores estacionários do ciclo diesel utilizando óleo diesel e biodiesel (B100). [S.1.]: AGRENER, 2006.

VOLPATO, C. E. S. et al. Desempenho de motor diesel quatro tempos alimentado com biodisel de oleo de soja (B 100). Ciência e Agrotecnologia, Lavras, v. 33, n. 4, p. 1125-1130, 2009. 